\title{
Spatial structure of the 8200 cal yr BP event in northern Europe
}

\author{
H. Seppä ${ }^{1}$, H. J. B. Birks ${ }^{2,3,4}$, T. Giesecke ${ }^{5}$, D. Hammarlund ${ }^{6}$, T. Alenius ${ }^{7}$, K. Antonsson ${ }^{8}$, A. E. Bjune ${ }^{2,3}$, \\ M. Heikkilä ${ }^{1}$, G. M. MacDonald ${ }^{9}$, A. E. K. Ojala ${ }^{7}$, R. J. Telford ${ }^{2,3}$, and S. Veski ${ }^{10}$ \\ ${ }^{1}$ Department of Geology, University of Helsinki, P.O. Box 64, 00014, Finland \\ ${ }^{2}$ Department of Biology, University of Bergen, Allégaten 55, 5007 Bergen, Norway \\ ${ }^{3}$ Bjerknes Centre for Climate Research, Allégaten 55, 5007 Bergen, Norway \\ ${ }^{4}$ Environmental Change Research Centre, University College London, 26 Bedford Way, London, WC1H OAP, UK \\ ${ }^{5}$ Department of Geography, University of Liverpool, Roxby Building, Liverpool, L69 7ZT, UK \\ ${ }^{6}$ GeoBiosphere Science Centre, Quaternary Sciences, Lund University, Sölvegatan 12, 22362 Lund, Sweden \\ ${ }^{7}$ Geological Survey of Finland, P.O. Box 96, 02151 Espoo, Finland \\ ${ }^{8}$ Department of Earth Sciences, Uppsala University, Villavägen 16, 75236 Uppsala, Sweden \\ ${ }^{9}$ Department of Geography, UCLA, 405 Hilgard Avenue, Los Angeles, CA 90095-1524, USA \\ ${ }^{10}$ Institute of Geology, Tallinn University of Technology, Ehitajate tee 5, 19086 Tallinn, Estonia
}

Received: 13 December 2006 - Published in Clim. Past Discuss.: 22 January 2007

Revised: 23 March 2007 - Accepted: 3 May 2007 - Published: 22 May 2007

\begin{abstract}
A synthesis of well-dated high-resolution pollen records suggests a spatial structure in the 8200 cal yr BP event in northern Europe. The temperate, thermophilous tree taxa, especially Corylus, Ulmus, and Alnus, decline abruptly between 8300 and 8000 cal yr BP at most sites located south of $61^{\circ} \mathrm{N}$, whereas there is no clear change in pollen values at the sites located in the North-European tree-line region. Pollen-based quantitative temperature reconstructions and several other, independent palaeoclimate proxies, such as lacustrine oxygen-isotope records, reflect the same pattern, with no detectable cooling in the sub-arctic region. The observed patterns challenges the general view of the widespread occurrence of the $8200 \mathrm{cal}$ yr BP event in the North Atlantic region. An alternative explanation is that the cooling during the $8200 \mathrm{cal}$ yr BP event took place mostly during the winter and spring, and the ecosystems in the south responded sensitively to the cooling during the onset of the growing season. In contrast, in the sub-arctic area, where the vegetation was still dormant and lakes ice-covered, the cold event is not reflected in pollen-based or lake-sediment-based records.
\end{abstract}

\section{Introduction}

High-resolution records have revealed that abrupt climate changes were frequent during the last glacial when regional temperature changes of as much as $8^{\circ} \mathrm{C}$ to $16^{\circ} \mathrm{C}$ may have occurred in a decade or less (Severinghaus and Brook, 1998;

Correspondence to: H. Seppä

(heikki.seppa@helsinki.fi)
Stocker, 2000; Alley et al., 2003; Schulz et al., 2004), but also during the early post-glacial period characterized by rapidly vanishing ice sheets (Clark et al., 2001, 2002). The precise origins and processes associated with these events remain controversial (Schulz et al., 2004), as do their spatial expressions (Alley et al., 2003; Wunsch, 2006), although most theories invoke the role of the Atlantic meridional overturning circulation (AMOC) and its sensitivity to freshening of the North Atlantic surface water by increased precipitation, runoff from surrounding landmasses, and abrupt fluxes of glacial melt-water (Clark et al., 2002).

Many records, especially from the North Atlantic region, provide evidence of a cold event at $8200 \mathrm{cal}$ yr BP that represents a unique climatic feature within the last 10,000 years in terms of magnitude and abruptness (e.g. Alley et al., 1997; von Grafenstein et al., 1998; Klitgaard-Kristensen et al., 1998; Johnsen et al., 2001; Spurk et al., 2002; Veski et al., 2004; Alley and Àgústsdóttir, 2005). Although it has been suggested that the cooling was linked to reduced solar output (Rohling and Pälike, 2005), there is accumulating evidence that the primary cause of the cooling was a pulse a cold freshwater released by a sudden drainage of the proglacial Laurentide lakes in North America to the North Atlantic at about $8500 \mathrm{cal} \mathrm{yr} \mathrm{BP}$, leading to a transient freshening and cooling of the North Atlantic Surface Water (NADW). This probably resulted in a weaker AMOC, and a consequent reduction of the northward heat transport and associated heat release in the North Atlantic region. Compelling support for this hypothesis is provided by the record of Ellison et al. (2006), showing that the near-bottom flow speed of the Iceland-Scotland Overflow Water, an important component

Published by Copernicus Publications on behalf of the European Geosciences Union. 


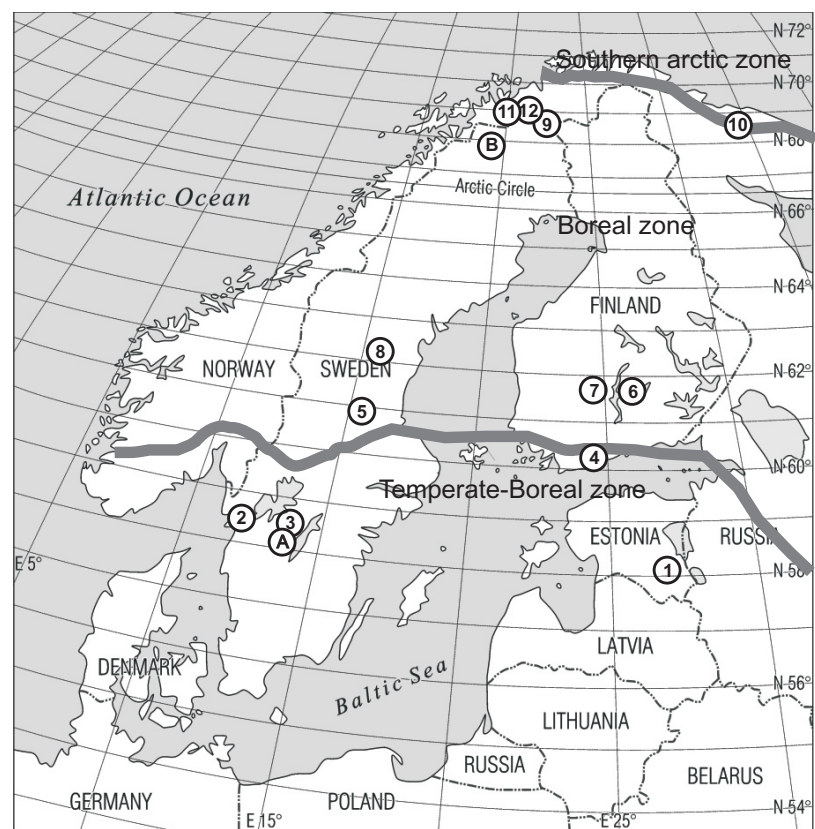

Fig. 1. The locations of sites (1-12) from which pollen-based temperature reconstructions used in this study have been obtained, together with sites $(1, \mathrm{~A}, \mathrm{~B})$ with oxygen-isotope records used for comparison (Table 1). The approximate boundaries of the main biomes in the region are shown. 1 = Lake Rouge, Estonia, $2=$ Lake Trehörningen, Sweden, 3 = Lake Flarken, Sweden, 4 = Lake Arapisto, Finland, $5=$ Lake Holtjärnen, Sweden, $6=$ Lake Laihalampi, Finland, 7 = Lake Nautajärvi, 8 = Lake Klotjärnen, Sweden, Finland, $9=$ Lake Tsuolbmajavri, Finland, $10=$ Lake KP-2, Russia, 11 = Lake Dalmutladdo, Norway, 12 = Lake Toskaljavri, Finland, A = Lake Igelsjön, Sweden, B = Lake Tibetanus, Sweden.

of the AMOC, declined significantly at the onset of the cold event. This is the first firm palaeoceanographic evidence for a reduction of the NADW formation. This theory is supported by climate models which, in accordance with palaeoclimatic records, simulate maximum cooling in the North Atlantic region in response to the drainage of the Laurentide lakes (Alley and Àgústsdóttir, 2005; LeGrande et al., 2006; Wiersma and Renssen, 2006; Wiersma et al., 2006).

One of the key regions for investigating the continentalscale impacts of the $8200 \mathrm{cal}$ yr BP cold event is Northern Europe, located downwind of the North Atlantic Ocean. The climatic conditions there are strongly dependent on the intensity of the North Atlantic Oscillation (NAO) and the associated westerly airflow, which is related to the strength of the AMOC and to the sea-surface temperatures in the North Atlantic (Hurrell, 1995; Rodwell et al., 1999; Hurrell et al., 2003; Wu and Rodwell, 2004; Stouffer et al., 20006). Thus, palaeoclimatic records from northern Europe can provide basis for testing potential processes associated with the 8200 cal yr BP cold event. Since the first reported occurrences of the cold event based, for example, on high- resolution pollen records (Snowball et al., 2001; Veski et al., 2004) and stable isotope records obtained from calcareous lake sediments (Hammarlund et al., 2003; Veski et al., 2004), the number of well-dated quantitative temperature reconstructions from this region has increased rapidly. This improving network of records with high time resolution now permits a more detailed spatial and temporal analysis of the climatic changes between 9500 to 7000 cal yr BP.

Here we examine high-resolution pollen-stratigraphical records produced with uniform methodology in northern $\mathrm{Eu}-$ rope along a sector that ranges from 55 to $70^{\circ} \mathrm{N}$ latitude and from 18 to $26^{\circ} \mathrm{E}$ longitude and includes two significant climatic gradients: a primary south-to-north gradient of falling temperature and a secondary west-to-east gradient of decreasing precipitation and oceanicity. We particularly aim to investigate the spatial patterns of vegetational and climatic change in order to observe if the evidence for the cold event shows consistent features or whether there are geographical differences in the amplitude or occurrence of the event along the two climatic gradients. In addition, we compare the highresolution pollen records with other, independent palaeoclimatic records of comparable time resolution, in particular oxygen-isotope records obtained on lacustrine carbonates.

\section{Material and methods}

There are numerous pollen diagrams available from northern Europe, but only a fraction of them have sufficient temporal resolution and chronological control to allow assessment of climate events of 200-300 years duration. Pollen records from 12 sites with adequate resolution and reliable chronologies were selected for this study (Fig. 1, Table 1). The number of analysed pollen samples for the last 10000 years ranges from 57 (Lake Trehörningen) to over two hundred (Lake Nautajärvi 260 and Lake Rouge 237), and the records selected have a minimum of six radiocarbon dates and in general smooth age-depth models. Two records (Lakes Nautajärvi and Rouge), have exceptionally precise chronologies based on annually laminated sediments (Ojala et al., 2003; Veski et al., 2004). At all sites the pollen percentage values have been calculated on the basis of the total sum of all terrestrial pollen and spore types.

In addition to the examination of individual pollen curves, pollen-stratigraphical data were used to derive a quantitative temperature record for each site for the early- to midHolocene. Two different temperature parameters were used in the quantitative reconstructions. July mean temperature $\left(T_{\text {jul }}\right)$ was reconstructed at four sites located in the northern tree-line region, whereas annual mean temperature $\left(T_{\mathrm{ann}}\right)$ was estimated for the rest of the sites located in the central or southern parts of the study area. The reason for this is that in the far north the growing season is confined to three or four summer months (MJJA) and a vegetation-based proxy such as pollen arguably predominantly represents summer 
Table 1. Geographical locations and references of the pollen and oxygen-isotope records discussed in the study.

\begin{tabular}{lcccl}
\hline & Lat. & Long. & Calibration model & Reference \\
\hline 1 Rouge, Estonia & $57^{\circ} 44^{\prime}$ & $26^{\circ} 54^{\prime}$ & $T_{\text {ann-3 }}$ & Veski et al., 2004 \\
A Igelsjön, Sweden & $58^{\circ} 28^{\prime}$ & $13^{\circ} 44^{\prime}$ & & Hammarlund et al., 2003, 2005 \\
2 Trehörningen, Sweden & $58^{\circ} 33^{\prime}$ & $11^{\circ} 36^{\prime}$ & $T_{\text {ann }}-3$ & Antonsson and Seppä, 2007 \\
3 Flarken, Sweden & $58^{\circ} 33^{\prime}$ & $13^{\circ} 44^{\prime}$ & $T_{\text {ann }}-3$ & Seppä et al., 2005 \\
4 Arapisto, Finland & $60^{\circ} 35^{\prime}$ & $24^{\circ} 05^{\prime}$ & $T_{\text {ann }}-2$ & Sarmaja-Korjonen and Seppä, 2007 \\
5 Holtjärnen, Sweden & $60^{\circ} 39^{\prime}$ & $15^{\circ} 56^{\prime}$ & $T_{\text {ann }}-3$ & this paper; Giesecke, 2005 \\
6 Laihalampi, Finland & $61^{\circ} 29^{\prime}$ & $26^{\circ} 04^{\prime}$ & $T_{\text {ann }}-1$ & Heikkilä and Seppä, 2003 \\
7 Nautajärvi, Finland & $61^{\circ} 48^{\prime}$ & $24^{\circ} 41^{\prime}$ & $T_{\text {ann }}-3$ & Ojala et al., 2007 \\
8 Klotjärnen, Sweden & $61^{\circ} 49^{\prime}$ & $16^{\circ} 32^{\prime}$ & $T_{\text {ann }}-3$ & this paper; Giesecke, 2005 \\
B Tibetanus, Sweden & $68^{\circ} 20^{\prime}$ & $18^{\circ} 42^{\prime}$ & & Hammarlund et al., 2002 \\
9 Tsuolbmajavri, Finland & $68^{\circ} 41^{\prime}$ & $22^{\circ} 05^{\prime}$ & $T_{\text {jul }}$ & Seppä and Birks, 2001 \\
10 KP Lake, Russia & $68^{\circ} 48^{\prime}$ & $35^{\circ} 19^{\prime}$ & $T_{\text {jul }}$ & this paper; Gervais et al., 2002 \\
11 Dalmutladdo, Norway & $69^{\circ} 10^{\prime}$ & $20^{\circ} 43^{\prime}$ & $T_{\text {jul }}$ & Bjune et al., 2004 \\
12 Toskaljavri, Finland & $69^{\circ} 12^{\prime}$ & $21^{\circ} 28^{\prime}$ & $T_{\text {jul }}$ & Seppä and Birks, 2002 \\
\hline
\end{tabular}

1 Ojala, A. E. K., Alenius, T., and Seppä, H.: Integration of the clastic-organic varve record from Finland with a pollen-based climate reconstruction for solving the Holocene seasonal temperature patterns in the high latitudes, The Holocene, submitted, 2007.

temperature conditions. No such generalization can be made in more southern parts of Fennoscandia, however, because there the growing season is considerably longer, starting often in March or April and continuing to October (Rötzer and Chmielewski, 2001; Walther and Linderholm, 2006). In addition, winter climatic conditions are important for the distribution and regeneration of many plant species, especially those restricted to the most oceanic parts along the west coast of Fennoscandia (Dahl, 1998). Thus the pollen records represent a mixture of taxa with different temperature requirements in relation to the seasons and annual mean temperature is probably a better justified climatic parameter to be reconstructed from pollen data in southern and central Fennoscandia than July or summer (JJA) mean temperature (Seppä et al., 2004).

Pollen-based temperature reconstructions were based on transfer functions derived from North-European pollenclimate calibration sets. These data sets are based on modern climate data from the Climate Normals period 1961-1990 and on modern pollen samples, collected from top surface sediment samples of small to medium-sized lakes. All samples were selected, collected, and analysed with standardised methods (see Seppä et al., 2004). The $T_{\text {jul }}$ records were based on 164 surface samples from Norway, 27 samples from northern Sweden, and 113 samples from Finland (Seppä and Birks, 2001). The $T_{\text {ann }}$ reconstructions were carried out using three different calibration subsets. Subset 1 consists of 113 samples from Finland, subset 2 includes 24 samples from Estonia in addition to the 113 Finnish samples (Seppä et al., 2004), and subset 3 includes 37 samples from Sweden in addition to the 113 Finnish samples and the 24 Estonian samples. Table 1 indicates which subset was used for each fossil record. The transfer functions were developed using
Table 2. The performance statistics of the pollen-climate calibration models used for producing the temperature records. RMSEP = root mean square error of prediction, $R^{2}=$ coefficient of determination between the observed temperature and that predicted by the model.

\begin{tabular}{lcccc}
\hline Model & number of samples & RMSEP & $R^{2}$ & max. bias \\
\hline$T_{\text {jul }}$ & 304 & $0.99^{\circ} \mathrm{C}$ & 0.71 & $3.94^{\circ} \mathrm{C}$ \\
$T_{\text {ann }}-1$ & 113 & $0.91^{\circ} \mathrm{C}$ & 0.85 & $2.12^{\circ} \mathrm{C}$ \\
$T_{\text {ann }}-2$ & 137 & $0.89^{\circ} \mathrm{C}$ & 0.88 & $2.13^{\circ} \mathrm{C}$ \\
$T_{\text {ann }}-3$ & 174 & $0.95^{\circ} \mathrm{C}$ & 0.88 & $2.10^{\circ} \mathrm{C}$ \\
\hline
\end{tabular}

weighted averaging partial least squares (WA-PLS) regression, a non-linear, unimodal regression and calibration technique commonly used in quantitative environmental reconstructions (ter Braak and Juggins, 1993; Birks, 1995, 2003). WA-PLS was implemented by the program CALIBRATE (S Juggins and CJF ter Braak unpublished program). All terrestrial pollen and spore types were included in the models, and were square-root transformed to stabilize their variances and to maximize "the signal to noise" ratio (Prentice, 1980). The performance statistics of the pollen-climate calibration sets are given in Table 2. In general the statistics indicate high performance of the models relative to other corresponding models based on various biological proxy techniques (Birks and Seppä, 2004). 
(a) Corylus

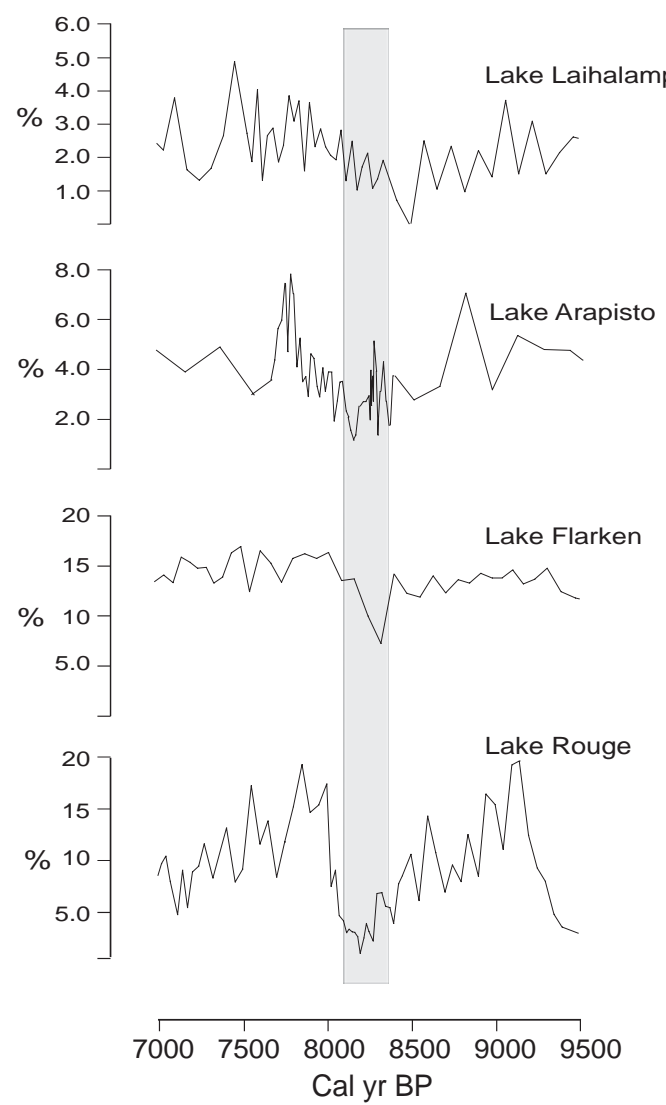

(b) Ulmus
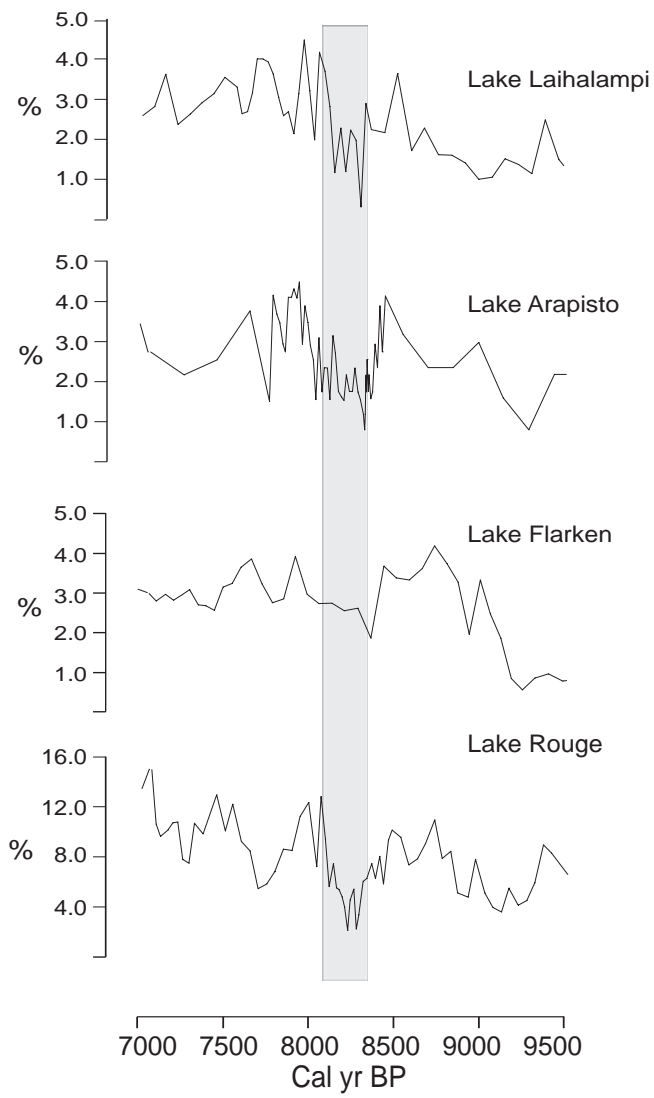

Fig. 2. Corylus and Ulmus pollen percentage curves at 9500 to 7000 cal yr BP from four sites in the southern and central parts of the study area. No records of these pollen types are shown from the sites in the far north of Europe because these thermophilous taxa do not occur there. See Fig. 1 for the locations of the sites.

\section{Results}

To show the details of the pollen-stratigraphical changes during the 8200 cal yr BP event in northern Europe, we focus on key pollen types. In northern Europe pollen types that mostly decline during the event, indicating either reduced populations and/or pollen productivity, likely caused by the cooling, are the thermophilous deciduous tree taxa, predominantly Corylus, Ulmus and Alnus. The types that usually increase are Betula and/or Pinus (Snowball et al., 2001; Veski et al., 2004; Seppä et al., 2005; Sarmaja-Korjonen and Seppä, 2007). The percentage pollen curves of Corylus and Ulmus are shown in Fig. 2. As these temperate deciduous tree taxa do not occur in the pollen records from the tree-line region, curves are shown only for the sites that are located in the southern and central part of the research area. Both taxa show a distinct and abrupt decline during the event at four sites, all located south of $61^{\circ} \mathrm{N}$. Corylus especially seems to respond strongly to the sudden cooling, its values dropping at Lake Rouge, for example, from $10-15 \%$ to below $5 \%$ at
$8250-8050$ cal yr BP, and the decline is almost equally distinct at the three other southernmost sites. The decline of Ulmus is of similar magnitude apart from the weak signal at Lake Flarken. At Lakes Laihalampi and Nautajärvi, both located north of $61^{\circ} \mathrm{N}$, Corylus does not decline during the cold event, but there is a relatively clear decline of Ulmus at Lake Laihalampi (Fig. 2).

Alnus pollen percentage curves are shown from eight sites (Fig. 3). Alnus is selected because it is the only thermophilous deciduous tree taxon whose pollen values continuously exceed $1 \%$ at all sites, including those at the northern tree-line. Alnus pollen is produced by two tree species, $A$. incana and A. glutinosa, of which the former is found up to $68^{\circ} \mathrm{N}$. The comparison of Alnus pollen records indicates a south to north gradient. There is a clear decline of Alnus values at the southern sites, especially at Lakes Rouge and Arapisto, whereas records from central Fennoscandia indicate little or no decline. Alnus pollen records from the Arctic tree-line region show no evidence of a decline. 

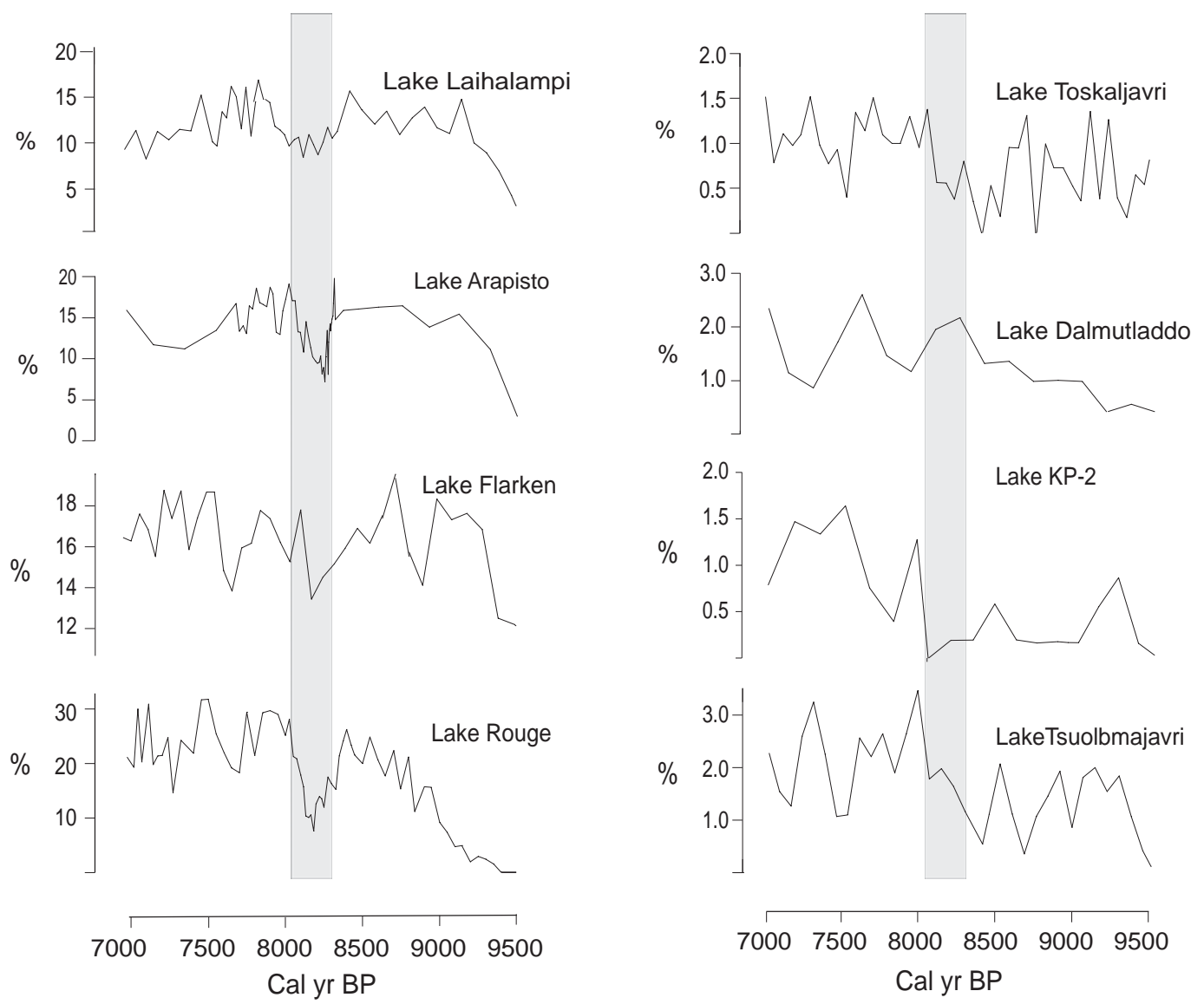

Fig. 3. Alnus pollen percentage curves at 9500 to 7000 cal yr BP from the eight sites in northern Europe. Sites on the left, showing a decline of the Alnus values at about $8300-8100$ cal yr BP, are from the southern part of the study area, whereas sites of the right, with no clear decline of Alnus, are from the North-European tree-line region. See Fig. 1 for the locations of the sites.

The pollen-based quantitative $T_{\text {ann }}$ reconstructions for the period $9500-7000$ cal yr BP show broadly the same pattern as the key indicator pollen types (Fig. 4). The results indicate a consistent cooling centred around $8200 \mathrm{cal} \mathrm{yr} \mathrm{BP}$ at the southernmost sites, especially at Lake Rouge in Estonia, Lake Flarken in Sweden, and Lake Arapisto in Finland. At all these sites there is a temperature drop of 0.5 to $1.5^{\circ} \mathrm{C}$. The cooling begins abruptly at about 8300 cal yr BP, lasts 200 to 300 years, and ends with a sudden temperature rise at about $8000 \mathrm{cal}$ yr BP. As the age-depth models for most sites were based on calibrated radiocarbon dates, it is realistic to relate the slight temporal differences between the records to the inevitable imprecision of the chronologies. In contrast, the $T_{\text {ann }}$ reconstructions from Lakes Holtjärnen, Laihalampi and Nautajärvi, all located north of $61^{\circ} \mathrm{N}$, show weak or no evidence of cooling at 8300-8000 cal yr BP. $T_{\text {jul }}$ records from the Fennoscandian tree-line region do not provide any evidence for a temperature change during the event. All four sites indicate a steady rise of $T_{\text {jul }}$ from 9400 cal yr BP toward the mid-Holocene, with variability that is not consistent between the records. Hence, the quantitative reconstruc- tions follow the same spatial pattern as the key pollen types, namely that there is a distinct cooling between 8300 and $8000 \mathrm{cal}$ yr BP in southern Fennoscandia and in the Baltic countries, weak or no cooling in central Fennoscandia, and no evidence of cooling in the tree-line region of northern Europe (Figs. 5 and 6).

A synthesis of the pollen-based evidence shows strikingly that the four records where the cooling is clearest are from the southernmost sites, located south of $61^{\circ} \mathrm{N}$. Biogeographically, they are located in the temperate-boreal (boreonemoral) zone today (Fig. 1) where the vegetation is characterized by the occurrence of nemoral thermophilous tree species such as Tilia cordata, Quercus robur, Corylus avellana, Ulmus glabra, Acer platanoides, and Fraxinus excelsior. All these tree species reach their northern distribution limits close to the border of the nemoral and boreal vegetation zones. In contrast, all the records where there is no cooling at $8200 \mathrm{cal}$ yr BP are from sites that are located north of $61^{\circ} \mathrm{N}$. Lakes Laihalampi and Nautajärvi are located in the southern boreal zone, where the dominant forest type is a mixture of conifers and birch, and Lakes Tsuolbmajavri, KP- 


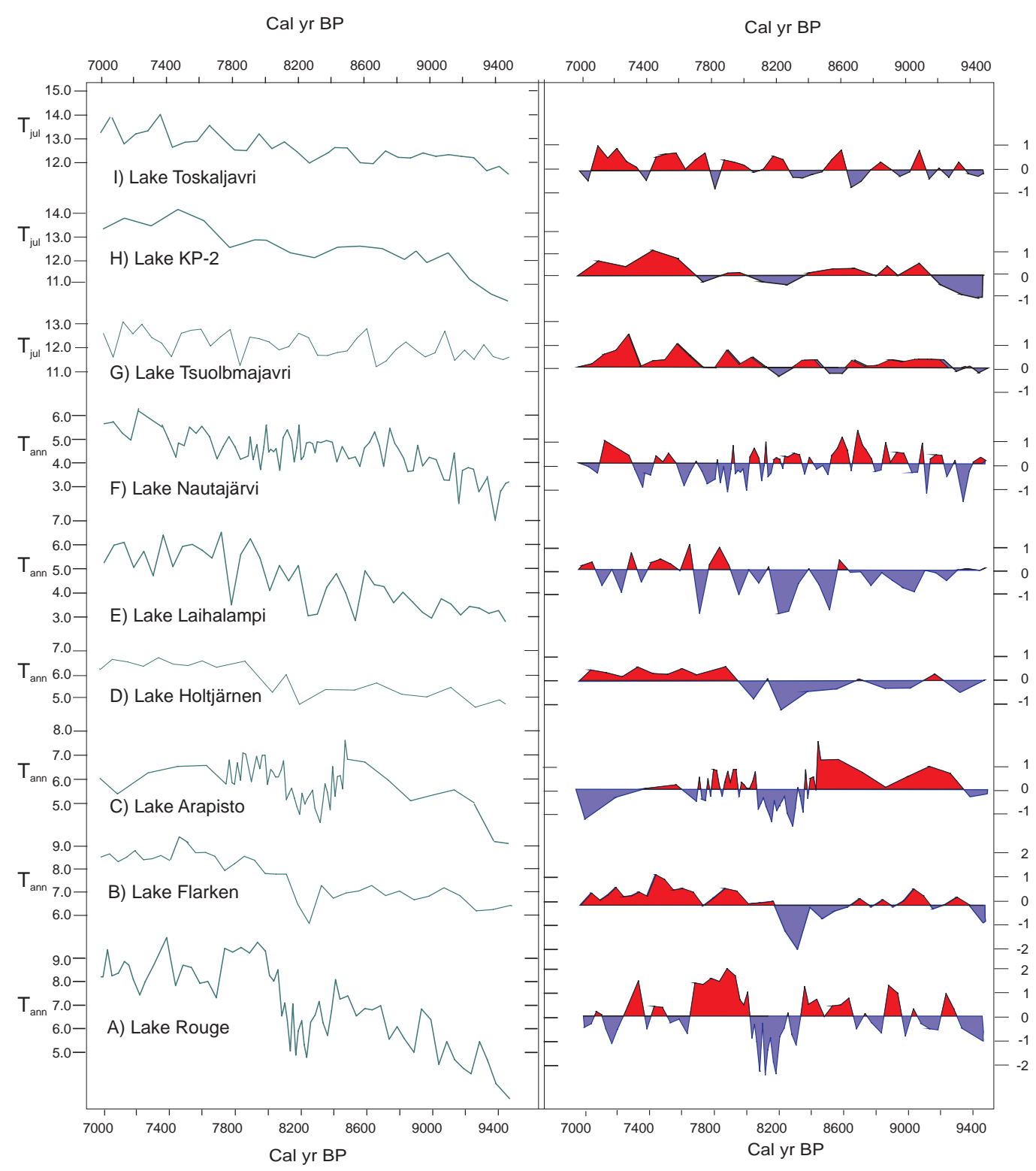

Fig. 4. Pollen-based $T_{\mathrm{ann}}$ and $T_{\mathrm{jul}}$ reconstructions at nine sites for the time period 9500 to 7000 cal yr BP arranged from the southernmost to the northernmost site. Original records are shown on the left hand side. The panel on the right shows the residuals after detrending the records with a third-order polynomial curve. See Figure 1 for the locations of the sites.

2, Dalmutladdo, and Toskaljavri are all situated within the northern ecotone of the boreal zone, with significant arcticalpine components in the surrounding vegetation.

\section{Discussion}

The relatively mild winter climate of northern Europe is a result of the influence of the Atlantic Ocean and the westerly airflow over the continent (Seager et al., 2002; Sutton et al., 2003). This influence is particularly strong during the positive phase of the NAO with strong westerly wind, greater advection of moist air off the Atlantic and onto the continent, and high temperature and precipitation even in northernmost Fennoscandia (Hurrell et al., 2003; Kryjov, 2004; Cook et al., 2005; Jaagus, 2006). The reverse holds true when the NAO has a negative mode and the westerly airflow is replaced by anticyclonic conditions and a predominantly continental airflow. The most probable scenario for cooling during the $8200 \mathrm{cal}$ yr BP cold event in northern Europe is that the sudden flux of cold freshwater perturbed the AMOC and led to lower sea-surface temperatures in the North Atlantic. As a consequence the heat transport from the Atlantic onto 


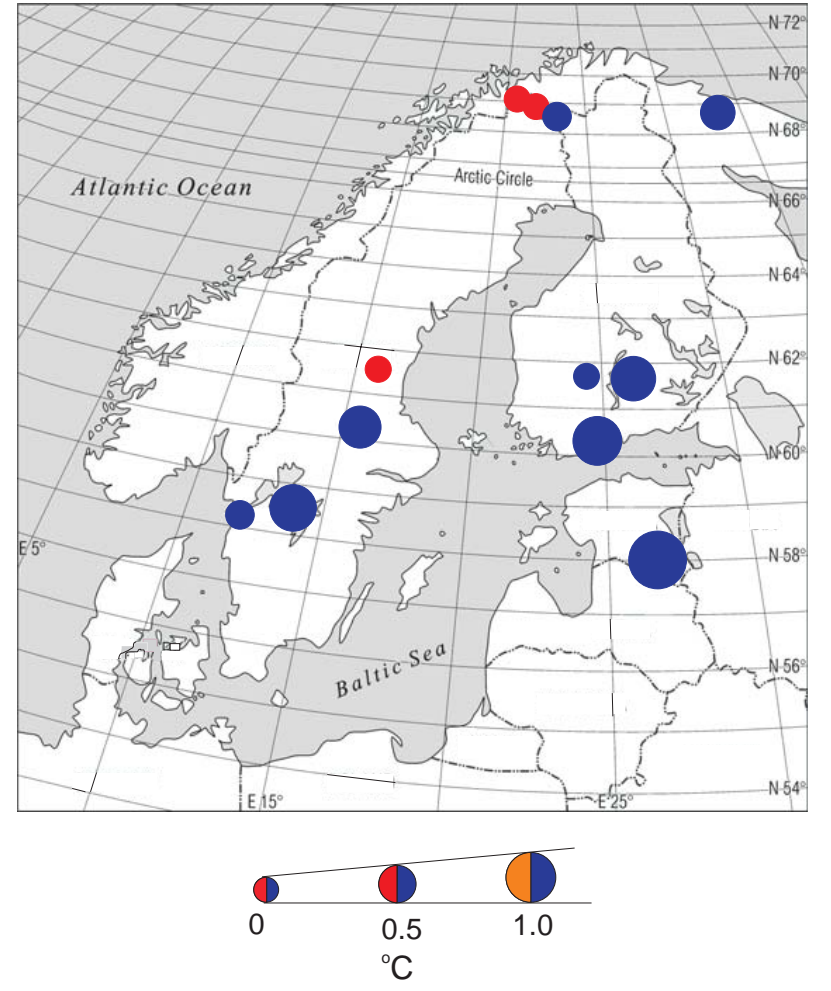

Fig. 5. Map showing the geographical pattern of the temperature change. The blue colour indicates cooling and red colour warming during the $8200 \mathrm{cal}$ yr BP event. The temperature deviation at the event is calculated as the difference between the mean temperature at $8350-8050 \mathrm{cal} \mathrm{yr} \mathrm{BP}$ and the mean for the periods $8850-8350$ and $8050-7550$ cal yr BP.

the continent decreased. The reason for this may have been a weaker generation of migratory cyclones and, in general, a weaker flow of mild oceanic air over northern Europe during winter (Veski et al., 2004; Hammarlund et al., 2005; Seppä et al., 2005). A related hypothesis suggests that the weaker oceanic airflow may have resulted from a major expansion of sea-ice cover in the North Atlantic and an associated reduction of the advection of heat from the ocean to the atmosphere (Wiersma and Renssen, 2006).

Against this background, it can be argued that the reconstructed longitudinal gradient towards a weaker signal in the North reflects realistically a geographical pattern of the magnitude of the $8200 \mathrm{cal} \mathrm{yr} \mathrm{BP}$ event. The cold event may have been caused by weakened westerly circulation during winter, so that the resulting decrease in oceanicity was particularly influential south of $\sim 60^{\circ} \mathrm{N}$ latitude and less significant in the far north of Fennoscandia. This explanation may seem paradoxical, given the presently strong influence of the North Atlantic and the NAO on the climate of northern Fennoscandia, particularly on the eastern side of the Scandes Mountains (Hurrell et al., 2003). It is also inconsistent with the results of modelling studies focusing on the

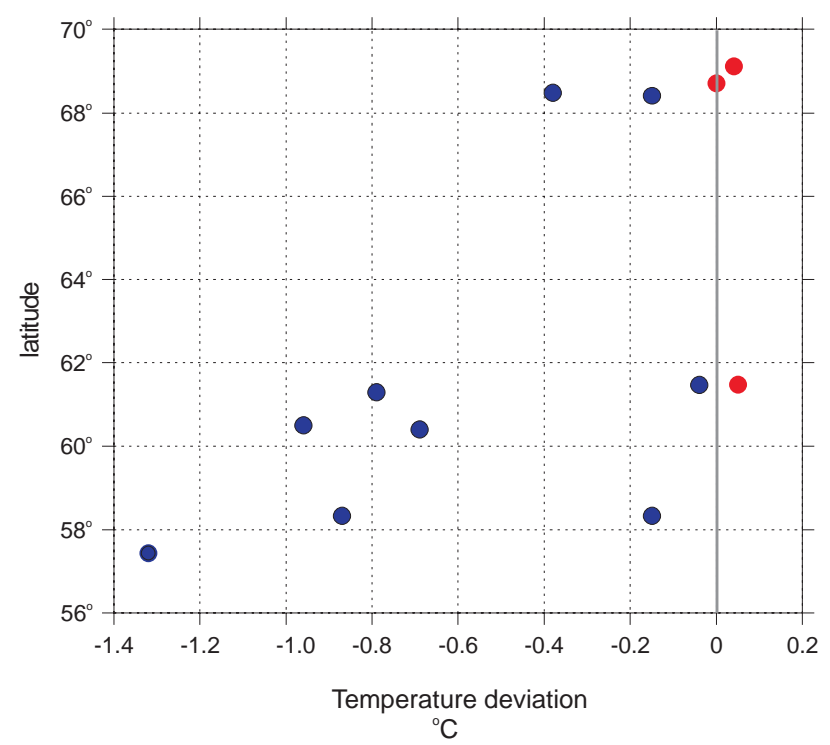

Fig. 6. Temperature deviation during the $8200 \mathrm{cal}$ yr BP event along a south-to-north gradient. Data from all 12 pollen-based records are included. The deviation is calculated by comparing the reconstructed average July mean temperature or annual mean temperature at $8350-8050 \mathrm{cal}$ yr BP relative to the mean temperature of the periods $8850-8350$ cal yr BP and $8050-7550$ cal yr BP.

8200 cal yr BP event (Renssen et al., 2001, 2002; Alley and Àgústsdóttir, 2005; LeGrande et al., 2006; Wiersma and Renssen, 2006), all indicating major, wide-spread cooling in the North Atlantic and the eastern Atlantic seaboard in response to weakening of the AMOC. Interestingly, however, the multimodel ensemble simulation based on models ranging from the earth system models of intermediate complexity to fully coupled atmosphere-ocean general circulation models indicates that a moderately small freshwater flux of $0.1 \mathrm{~Sv}$ $\left(1 \mathrm{~Sv}=10^{6} \mathrm{~m}^{3} \mathrm{~s}^{-1}\right)$ may lead to a strong cooling in the North Atlantic south of Greenland but a $1-2^{\circ} \mathrm{C}$ warming over the Barents Sea and the Nordic Sea east of Svalbard and no significant temperature change on the northern Fennoscandian mainland (Stouffer et al., 2006).

An alternative hypothesis can also explain the observed geographical pattern in the records. Model simulations consistently indicate that the $8200 \mathrm{cal}$ yr BP event was predominantly a winter (DJF) and spring (MAM) event, as is also supported by the majority of palaeoclimate records from various parts of Europe (Alley and Àgústsdóttir, 2005; Wiersma and Renssen, 2006). The tree taxa that show strong responses to the $8200 \mathrm{cal}$ yr BP event, Alnus, Corylus, and $U l$ $m u s$, start flowering in early spring, in central Europe often in February-March and in southern and central Fennoscandia in March-April (Jäger et al., 1996; Kasprzyk et al., 2004). The start of their flowering and plant development is in general dependent on air temperature (Wielgolaski, 1999; Aasa et al., 2004) and if an abrupt change to cold winters and cold 


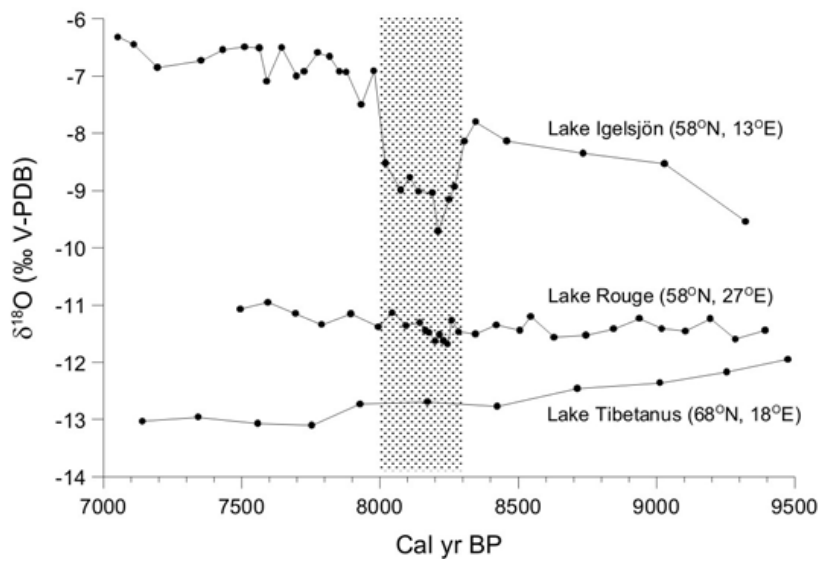

Fig. 7. Comparison of $\delta^{18} \mathrm{O}$ records obtained on fine-grained sedimentary calcite from small lakes $(0.5-4$ ha) in the study area, Lakes Igelsjön (Hammarlund et al., 2003, 2005; Seppä et al., 2005), Rouge (Veski et al., 2004), and Tibetanus (Hammarlund et al., 2002). See Fig. 1 for the locations of the sites.

early springs with frequent frosts took place at the beginning of the event, it may have led to major damage to flowers and male catkins, resulting in reduced pollen productivity, sexual regeneration, and population sizes. This hypothesis is supported by investigations of the relationships between modern phenological phenomema and climate patterns (Kramer et al., 2000) and by modern pollen monitoring studies in Europe. For example, cold weather conditions during winter and spring result in a reduction of the annual pollen productivity and a delay of the start of the pollen season of tree species that are favoured by high temperatures, such as Alnus, Corylus and Ulmus (Andersen, 1972; Frenguelli, 1993; Jäger et al., 1996; Frei, 1998; Spieksma et al., 2003; Kasprzyk et al., 2004). The clear decline of the pollen percentages of these taxa may therefore reflect their phenological inability to adapt to an abrupt lowering of the winter and early spring temperatures during the $8200 \mathrm{cal}$ yr BP event.

In contrast, northernmost Fennoscandia, north of $68^{\circ} \mathrm{N}$, is characterized by a markedly different climatic and phenological situation. Here winter conditions with subzero diurnal mean temperatures and abundant snow remain long into April. The growing season starts in late May or early June (Linderholm et al., 2006) and its duration is typically only 100-150 days. Winter temperatures can be extremely low, down to below $-40^{\circ} \mathrm{C}$, and only the most frost-resistant tree species thrive, i.e. the main northern forest components Pinus sylvestris, Picea abies, and Betula (B. pubescens and B. pendula) (Grace et al., 2002). For example, climate chamber experiments have shown that Pinus sylvestris can tolerate temperatures as low as $<-72^{\circ} \mathrm{C}$ during the winter while its needles can be lethally damaged when exposed to $-10^{\circ} \mathrm{C}$ during the summer (Repo, 1992; Beck et al., 2004). The continental conifer species Picea abies is also adapted to cold winters as its radial growth is positively correlated with low winter temperatures and negatively correlated with high winter temperatures (Mäkinen et al., 2000). Of the deciduous tree taxa that show strong responses to the $8200 \mathrm{cal} \mathrm{yr} \mathrm{BP}$ event in the southern part of the study region, only Alnus grows in northern Fennoscandia, albeit not north of about $68^{\circ}$ N. However, Alnus incana is less sensitive to cold periods during the late winter and early spring in the far north, because of phenological adaptation of the beginning of flowering, bud break, and leaf expansion, these processes taking place usually in May to June, about two months later than in the south.

If the cooling took place mostly during winter and early spring, the occurrence, regeneration, and pollen productivity of the northern-boreal tree taxa may not have been significantly affected, and the lack of pollen-stratigraphical responses to the cold event may reflect largely unaltered climatic conditions during the short growing season of these taxa. Many other proxy records that are independent of vegetation patterns indicate a weaker signal for the $8200 \mathrm{cal} \mathrm{yr} \mathrm{BP}$ event towards northern Fennoscandia. In western Scandinavia records based on loss-on-ignition analysis of lake sediments reveal a substantial climatic perturbation and clearly decreased aquatic productivity at about $8200 \mathrm{cal}$ yr BP (Nesje et al., 2001; Bergman et al., 2005). However, in northern Fennoscandia the same methods do not display equally clear evidence for a cooling. For example, a high-resolution reconstruction of Holocene equilibrium-line altitude changes from the Lyngen peninsula on the northwestern coast of Norway does not show any sign of glacier growth between 8500 and 7500 cal yr BP (Bakke et al., 2005), neither does the record of bacterial magnetite from the Lyngen peninsula indicate any cold excursion during the 8200 cal yr BP event (Paasche et al., 2004). Chironomid-based temperature reconstructions from northern Finland and Sweden do not indicate any cooling between 8300 and 8000 cal yr BP (Rosén et al., 2001; Bigler et al., 2002, 2003; Korhola et al., 2002; Seppä et al., 2002; Larocque and Hall, 2003, 2004). Similarly, quantitative and qualitative reconstructions from the Kola Peninsula in northwestern Russia do not document any cooling at 8200 cal yr BP (Jones et al., 2004). Korhola et al. (1999) and Bigler et al. (2006) report a cooler period at about 8300 to $8000 \mathrm{cal} \mathrm{yr} \mathrm{BP}$ in diatom-based $T_{\text {jul }}$ reconstructions from the northwestern Fennoscandian tree-line region, but it is unclear whether these results represent summer cooling or are more related to changes in the length of the lake ice-cover season, which may be the most important climate-related feature reflected in diatom records from alpine regions (Lotter and Bigler, 2000; Sorvari et al., 2002).

Independent evidence of a considerable influence of winter cooling on the general climatic character and expression of the $8200 \mathrm{cal}$ yr BP event in parts of northern Europe is provided by oxygen-isotope records $\left(\delta^{18} \mathrm{O}\right)$ obtained on finegrained sedimentary calcite from small lakes in the study area. Although relatively few records are available, and in spite of complications arising from site-specific hydrological characteristics, some relevant conclusions can be derived 
from such a comparison (Fig. 7). The Lake Igelsjön $\delta^{18} \mathrm{O}$ record from southern Sweden (Fig. 1) is sensitive to changing hydrology, with periods of ${ }^{18} \mathrm{O}$-enrichment reflecting mainly elevated evaporation/inflow ratio of the basin under warm and dry summer conditions (Hammarlund et al., 2003). The strong isotopic response to the $8200 \mathrm{cal}$ yr BP event therefore predominantly reflects an increase in net precipitation during the summer (Hammarlund et al., 2005), perhaps augmented by a generally shorter ice-free season. However, as demonstrated by Seppä et al. (2005), about $40 \%$ of the decrease in $\delta^{18} \mathrm{O}$ during the event can be attributed to a depletion in ${ }^{18} \mathrm{O}$ of annual precipitation and groundwater, which is likely coupled to a large extent to colder and longer winters. The effect of such a change in winter conditions is also manifested as a slight depletion in ${ }^{18} \mathrm{O}$ at $8200 \mathrm{cal} \mathrm{yr} \mathrm{BP}$ in the Lake Rouge record from southern Estonia (Veski et al., 2004), which more directly reflects $\delta^{18} \mathrm{O}$ of precipitation.

Oxygen-isotope data of comparable resolution are not available from northern Fennoscandia, but the Lake Tibetanus $\delta^{18} \mathrm{O}$ record from northernmost Sweden, close to the Atlantic coast (Hammarlund et al., 2002), does not reflect any climatic change at this stage. Supportive evidence of the absence of an oxygen-isotope response at $8200 \mathrm{cal} \mathrm{yr} \mathrm{BP} \mathrm{in}$ this part of Fennoscandia is provided by the more highly resolved $\delta^{18} \mathrm{O}$ record from the SG93 speleothem near the Arctic Circle in Norway (Lauritzen et al., 1999). Although interpreted differently by the authors, the SG93 record exhibits a general depletion in ${ }^{18} \mathrm{O}$ with time during the early Holocene, consistent with the long-term evolution of $\delta^{18} \mathrm{O}$ of precipitation as inferred from the Lake Tibetanus data (Hammarlund et al., 2002). It cannot be excluded that the potential effect of a pronounced winter cooling, and an associated depletion in $\delta^{18} \mathrm{O}$ of precipitation, on the two latter records from northwestern Scandinavia was offset by lowered summer temperatures during the event, leading to ${ }^{18} \mathrm{O}$-enrichment of lacustrine and speleothem calcite. However, it appears likely from these data that the weakening of the AMOC during the $8200 \mathrm{cal}$ yr BP event and the associated cooling of the North Atlantic Ocean, induced a southward displacement of the Polar Front and the westerlies in winter (Magny et al., 2003), giving rise to a general anti-cyclonic circulation pattern over northern Europe. Such a scenario may be invoked to explain the greater inferred cooling in the southern part of the study area in response to enhanced continentallity (Fig. 5), as well as parts of the stronger isotopic response in southern Sweden as compared to Estonia (Fig. 7), where the change was of lesser magnitude due to a relatively continental baseline climate.

\section{Conclusions}

The assessment of the regional impact of the 8200 cal yr BP event is based on a survey of records of positive evidence in the increasingly dense network of temperature-sensitive proxy records. Such a survey is a delicate and difficult process, as the palaeorecords are typically noisy and it is difficult to distinguish regionally restricted and representative anomalies. Furthermore, ignoring records with negative evidence can cause bias in such an assessment. In northern Europe, a synthesis of negative and positive evidence from pollen-based temperature reconstructions indicates a spatial pattern in the $8200 \mathrm{cal}$ yr BP event, with more distinct evidence of the cooling in the Baltic countries and in southern Fennoscandia than in the central and northernmost parts of Fennoscandia and adjacent areas. Given the evidence of the wide-spread nature of the $8200 \mathrm{cal}$ yr BP event in the NorthAtlantic region (Alley and Àgústsdóttir, 2005; Wiersma and Renssen, 2006) and the Barents Sea (Duplessy et al., 2004), a cooling probably took place all over northern Europe, including the tree-line region, but, as the cooling was predominantly a winter and spring event, taking place before the start of the growing season or before the break-up of lake ice in the north, it is not recorded in the quantitative and qualitative climate records obtained from the far north of northern Europe. However, on the basis of evidence presented here we cannot rule out a latitudinal gradient in the magnitude of the event, with a more pronounced cooling in the south and less or no cooling in the north. It may be possible to test these two hypotheses in the future by developing and applying specific palaeoecological techniques such as analyses of sedimentary chrysophyte cysts (Kamenik and Schmidt, 2005; Pla and Catalan, 2005), clacoceran ephippia (SarmajaKorjonen, 2004), or diatom records from alpine lakes (Lotter and Bigler, 2000) as they may have the potential for reflecting the length of the winter ice-cover of the lakes, hence providing insights into the winter temperature changes during the event.

If the muted response to the 8200 cal yr BP event at the tree-line sites results from the insensitivity of the palaeoclimatic records, then an important implication is that the northern tree-line regions, and in a more general sense, the cold regions of the Earth, may not always be optimal targets for palaeoclimatic reconstruction. In these regions the biological activity is to a great extent restricted to the short growing season during the summer months, whereas during the long and cold winter both terrestrial and aquatic ecosystems are dormant and therefore less sensitive to temperature changes. Consequently, biological proxy techniques such as pollen and chironomid records reflect predominantly summer temperatures in these regions. The same proxies in regions with a longer biologically active period, such as the ecotone between the temperate and boreal zones, are more sensitive to spring, autumn and perhaps winter temperatures. The evidence associated with the $8200 \mathrm{cal}$ yr BP event provides therefore a prime example of the importance of site selection in palaeoclimatological and palaeoecological studies. 
Acknowledgements. This study is part of the projects "Highresolution climate reconstructions in eastern Europe", funded by the Academy of Finland, and "Responses of boreal ecosystem carbon exchanges to changing environments in different spatiotemporal scales (REBECCA)", funded by the Helsinki University Environmental Research Centre (HERC).

Edited by: V. Masson-Delmotte

\section{References}

Aasa, A., Jaagus, J., Ahas, R., and Sepp, M.: The influence of atmospheric circulation on plant phenological phases in central and eastern Europe, Int. J. Climatol., 24, 1551-1564, 2004.

Alley, R. B. and Àgústsdóttir, A. M.: The 8k event: cause and consequences of a major Holocene abrupt climate change, Quatern. Sci. Rev., 10-11, 1123-1149, 2005.

Alley, R. B., Mayewski, P. A., Sowers, T., Stuiver, M., Taylor, K. C., and Clark, P. U.: Holocene climatic instability: A prominent, widespread event 8200 yr ago, Geology, 25, 483-486, 1997.

Alley, R. B., Marotzke, J., Nordhaus, W. D., Overpeck, J. T., Peteet, D. M., Pielke Jr., R. A., Pierrehumbert, R. T., Rhines, P. B., Stocker, T. F., Talley, L. D., and Wallace, J. M.: Abrupt Climate Change, Science, 299, 2005-2010, 2003.

Andersen, S. T.: Influence of climatic variation on pollen season severity in wind-pollinated trees and herbs, Grana, 19, 47-52, 1980.

Antonsson, K. and Seppä, H.: Holocene temperature and forest dynamics in Bohuslän, SW Sweden, Boreas, in press, 2007.

Bakke, J., Dahl, S. O., Paasche, Ø., Løvlie, R., and Nesje, A.: Glacier fluctuations, equilibrium-line altitudes and palaeoclimate in Lyngen, northern Norway, during Lateglacial and Holocene, The Holocene, 15, 518-540, 2005.

Beck, E. H., Heim, R., and Hansen, J.: Plant resistance to cold stress: Mechanism and environmental signals triggering frost hardening and dehardening, J. Bioscience, 29, 449-459, 2004.

Bergman, J., Hammarlund, D., Hannon, G., Barnekow, L., and Wohlfarth, B.: Deglacial vegetation succession and Holocene tree-limit dynamics in the Scandes Mountains, west-central Sweden: stratigraphic data compared to megafossil evidence, Review of Palaeobotany and Palynology, 134, 129-151, 2005.

Bigler, C., Larocque, I., Peglar, S. M., Birks, H. J. B., and Hall, R.: Quantitative multiproxy assessment of long-term patterns of Holocene environmental change from a small lake near Abisko, northern Sweden, The Holocene, 12, 481-496, 2002.

Bigler, C., Grahn, E., Larocque, I., Jeziorski, A., and Hall, R.: Holocene environmental change at Lake Njulla (999 m a. s. 1.), northern Sweden: a comparison with four small nearby lakes along an altitudinal gradient, J. Paleolimnol., 29, 13-29, 2003.

Bigler, C., Barnekow, L., Heinrichs, M. L., and Hall, R. I.: Holocene environmental history of Lake Vuolep Njakajaure (Abisko National Park, northern Sweden) reconstructed using biological proxy indicators, Vegetation History and Archaeobotany, 15, 309-320, 2006.

Birks, H. J. B.: Quantitative palaeoenvironmental reconstructions, in: Statistical modeling of quaternary science data, edited by: Maddy, D. and Brew, J. S., Technical Guide 5. Quaternary Research Association, Cambridge, 161-254, 1995.
Birks, H. J. B.: Quantitative palaeoenvironmental reconstructions from Holocene biological data, in: Global Change in the Holocene, edited by: Mackay, A., Battarbee, R. W., Birks, H. J. B., and Oldfield, F., Arnold, London, 107-123, 2003

Birks, H. J. B. and Seppä, H.: Pollen-based reconstructions of lateQuaternary climate in Europe - progress, problems, and pitfalls, Acta Palaeobotanica, 44, 317-334, 2004.

Bjune, A. E., Birks, H. J. B., and Seppä, H.: Holocene climate and vegetation history on a continental-oceanic transect in northern Fennoscandia based on pollen and plant macrofossils, Boreas, 33, 211-223, 2004.

Clark, P. U., Marshall, S. J., Clarke, G. K. C., Hostetler, S. W., Licciardi, J. M., and Teller, J. T.: Freshwater forcing of abrupt climate change during the last glaciation, Science, 293, 283-287, 2001.

Clark, P. U., Pisias, N. G., Stocker, T. S., and Weaver, A. J.: The role of the Atlantic thermohaline circulation in abrupt climate change, Nature, 415, 863-869, 2002.

Cook, B. I., Smith, T. M., and Mann, M. E.: The North Atlantic Oscillation and regional phenology prediction over Europe, Global Change Biol., 11, 1-8, 2005.

Dahl, E.: The phytogeography of Northern Europe, Cambridge University Press, Cambridge, 297 pp., 1998.

Duplessy, J. C., Cortijo, E., and Kallel, N.: Marine records of Holocene climate variations, Comptes Rendus Geoscience, 337, 87-95, 2005.

Ellison, C. R. W., Chapman, M. R., and Hall, I. R.: Surface and Deep Ocean Interactions During the Cold Climate Event 8200 Years Ago, Science, 312, 1929-1932, 2006.

Frei, T.: The effects of climate change in Switzerland 1969-1996 on airborne pollen quantities from hazel, birch and grass, Grana, 37, 172-179, 1998.

Frenguelli, G., Spieksma, F. Th. M, Bricchi, E., Romano, B., Mincigrucci, G., Nikkels, A. H., Dankaart, W., and Ferranti, F.: The influence of air temperature on the starting dates of the pollen season of Alnus and Populus, Grana, 30, 196-200, 1991.

Gervais, B. R., MacDonald, G. M., Snyder, J. A., and Kremenetski, C. V.: Pinus sylvestris treeline development and movement on the Kola Peninsula of Russia: pollen and stomate evidence, J. Ecol., 90, 627-638, 2002.

Giesecke, T.: Holocene dynamics of the southern boreal forest in Sweden, The Holocene, 15, 858-872, 2005.

Grace, J., Berninger, F., and Nagy, L.: Impacts of climate change on tree line, Annals of Botany, 90, 537-544, 2002.

Hammarlund, D., Barnekow, L., Birks, H. J. B., Buchardt, B., and Edwards, T. W. D.: Holocene changes in atmospheric circulation recorded in the oxygen-isotope stratigraphy of lacustrine carbonates from northern Sweden, The Holocene, 12, 339-351, 2002.

Hammarlund, D., Björck, S., Buchardt, B., Israelson, C., and Thomsen, C. T.: Rapid hydrological changes during the Holocene revealed by stable isotope records of lacustrine carbonates from Lake Igelsjön, southern Sweden, Quatern. Sci. Rev., 22, 353 $370,2003$.

Hammarlund, D., Björck, S., Buchardt, B., and Thomsen, C. T.: Limnic responses to increased effective humidity during the 8200 cal. yr BP cooling event in southern Sweden, J. Paleolimnol., 34, 471-480, 2005.

Heikkilä M. and Seppä, H.: A 11,000 yr palaeotemperature reconstruction from the southern boreal zone of Finland, Quatern. Sci. 
Rev., 22, 541-554, 2003.

Hurrell, J. W.: Decadal trends in the North Atlantic Oscillation: Regional temperatures and precipitation, Science, 269, 676-679, 1995.

Hurrell, J. W., Kushnir, Y., Ottersen, G., and Visbeck, M.: On overview of the North Atlantic Oscillation, in: The North Atlantic Oscillation: Climatic Significance and Environmental Impact, edited by: Hurrell, J. W., Geophysical Monograph, Americal Geophysical Union, 1-35, 2003.

Jaagus, J.: Climate changes in Estonia during the second half of the 20th century in relationship with changes in large-scale atmospheric circulation, Theor. Appl. Climatol., 83, 77-88, 2006.

Jäger, S., Nilsson, S., Berggren, B., Pessi, A.-M., Helander, M., and Ramfjord, H.: Trends of some airborne tree pollen in the Nordic countries and Austria, 1980-1993, Grana, 35, 171-178, 1996.

Johnsen, S. J., Dahl-Jensen, D., Gundestrup, N., Stefensen, J. P., Clausen, H. B., Miller, H., Masson-Delmotte, V., Sveinbjörnsdottir, A. E., and White, J.: Oxygen isotope and palaeotemperature records from six Greenland ice core stations: Camp Century, Dye-3, GRIP, GISP2, Renland and NorthGRIP, J. Quatern. Sci., 16, 299-307, 2001.

Jones, V. J., Leng, M., Solovieva, N., Sloane, H. J., and Tarasov, P.: Holocene climate of the Kola Peninsula: evidence from the oxygen isotope record of diatom silica, Quatern. Sci. Rev., 23, 833-839, 2004.

Kamenik, C. and Schmidt, R.: Chrysophyte resting stages: a tool for reconstructing winter/spring climate from Alpine lake sediments, Boreas, 34, 477-489, 2005.

Kasprzyk, I., Uruska, A., Szczepanek, K., Latalowa, M., Gawel, J., Harmata, K., Myszkowa, D., Stach, A., and Stepalska, D.: Regional differentiation in the dynamics of the pollen seasons of Alnus, Corylus and Fraxinus in Poland (preliminary results), Aerobiologia, 20, 141-151, 2004.

Klitgaard-Kristensen, D., Sejrup, H.P., Haflidason, H., Johnsen, S. and Spurk, M.: A regional 8200 cal. yr BP cooling event in northwest Europe, induced by final stages of the Laurentide ice-sheet deglaciation. Journal of Quaternary Science 13, 165-169, 1998.

Korhola, A., Weckström, J., Holmström, L., and Erästö, P.: A quantitative Holocene climatic record from diatoms in Northern Fennoscandia, Quatern. Res., 54, 284-294, 1999.

Korhola, A., Vasko, K., Toivonen, H., and Olander, H.: Holocene temperature changes in northern Fennoscandia reconstructed from chironomids using Bayesian modelling, Quatern. Sci. Rev., 21, 1841-1860, 2002.

Kramer, K., Leinonen, I., and Loustau, D.: The importance of phenology for the evaluation of impact of climate changes on growth of boreal, temperate and Mediterranean forests ecosystems: an overview, Int. J. Biometeorol., 44, 67-75, 2000.

Kryjov, V. N.: Searching for circulation patterns affecting North Europe annual temperature, Atmos. Sci. Lett., 5, 23-34, 2004.

Larocque, I. and Hall, R. I.: Chironomids as quantitative indicators of mean July air temperature, validation by comparison with century-long meteorological records from northern Sweden, J. Paleolimnol., 29, 475-493, 2003.

Larocque, I. and Hall, R. I.: Holocene temperature estimates and chironomid community composition in the Abisko Valley, northern Sweden, Quatern. Sci. Rev., 23, 2453-2465, 2004.

Lauritzen, S.-E. and Lundberg, J.: Calibration of the speleothem delta function: an absolute temperature record for the Holocene in northern Norway, The Holocene, 9, 659-669, 1999

LeGrande, A. N., Schmidt, G. A., Shindell, D. T., Field, C. V., Miller, R. L., Koch, D. M., Faluvegi, G., and Hoffman, G.: Consistent simulations of multiple proxy responses to an abrupt climate change event, Proceeding of the National Academy of Sciences, 103, 837-842.

Lotter, A. F. and Bigler, C.: Do diatoms in the Swiss Alps reflect the length of ice-cover?, Aquat. Sci., 62, 125-141, 2000.

Mäkinen, H., Nöjd, P., and Mielikäinen, K.: Climatic signal in annual growth variation of Norway spruce (Picea abies) along a transect from central Finland to the Arctic timberline, Canadian Journal of Forest Research, 30, 769-777, 2000.

Magny, M., Bégeot, C., Guiot, J., and Peyron, O.: Contrasting patterns of hydrological changes in Europe in response to Holocene climate cooling phases, Quatern. Sci. Rev., 22, 1589-1596.

Nesje, A. and Dahl, S. O.: The Greenland 8200 cal. yr BP event detected in loss-on-ignition profiles in Norwegian lacustrine sediment sequences, J. Quatern. Sci., 16, 155-166, 2001.

Ojala, A. E. K. and Tiljander, M.: Testing the fidelity of sediment chronology: comparison of varve and paleomagnetic results from Holocene lake sediments from central Finland, Quatern. Sci. Rev., 22, 1787-1803, 2003.

Paasche, Ø., Løvlie, R., Dahl, S. O., Bakke, J., and Nesje, A.: Bacterial magnetite in lake sediments: late glacial to Holocene climate and sedimentary changes in northern Norway, Earth Planet. Sci. Lett., 223, 319-333, 2004.

Pla, S. and Catalan, J.: Chrysophyte cysts from lake sediments reveal the submillennial winter/spring climate variability in the northwestern Mediterranean region throughout the Holocene, Clim. Dyn., 24, 264-278, 2005.

Prentice, I. C.: Multidimensional scaling as a research tool in Quaternary palynology: a review of theory and methods, Review of Palaeobotany and Palynology, 31, 71-104, 1980.

Renssen, H., Goosse, H., and Fichefet, T.: Modeling the effect of freshwater pulses on the early Holocene climate: the influence of high-frequency climate variability, Paleoceanography, 17, 1-16, 2002.

Renssen, H., Goosse, H., Fichefet, T., and Campin, J.-M.: The 8.2 kyr BP event simulated by a global atmosphere-seaice-ocean model, Geophys. Res. Lett., 28, 1567-1570, 2001.

Repo, T.: Seasonal changes of frost hardiness in Picea abies and Pinus sylvestris in Finland, Canadian Journal of Forest Research 22, 1949-1957, 1992.

Rodwell, M. J., Rowell, D. P., and Folland, C. K.: Oceanic forcing of the wintertime North Atlantic Oscillation and European climate, Nature, 398, 320-323, 1999.

Rohling, E. J. amd Pälike, H.: Centennial-scale climate cooling with a sudden cold event around 8,200 years ago, Nature, 434, 975-979, 2005.

Rosén, P., Segerström, U., Eriksson, L., Renberg, I., and Birks, H. J. B.: Holocene climate change reconstructed from diatoms, chironomids, pollen and near-infrared spectroscopy at an alpine lake (Sjuodjijaure) in northern Sweden, The Holocene, 11, 551-562, 2001.

Rötzer, T. and Chmielewski, F.-M.: Phenological maps of Europe, Clim. Res., 18, 259-257, 2001.

Sarmaja-Korjonen, K.: Chydorid ephippia as indicators of past environmental changes - a new method, Hydrobiologia, 526, 129 136, 2004. 
Sarmaja-Korjonen, K. and Seppä, H.: Abrupt and consistent responses of aquatic and terrestrial ecosystems during the $8200 \mathrm{cal}$ yr cold event - a lacustrine record from Lake Arapisto, Finland, The Holocene, in press, 2007.

Schulz, M., Paul, A., and Timmermann, A.: Glacial-interglacial contrast in climate variability at centennial-to-millennial timescales: observations and conceptual model, Quatern. Sci. Rev., 23, 2219-2230, 2004.

Seager, R., Battisti, D. S., Yin, J., Gordon, N., Naik, N., Clement, A. C., and Cane, M. A.: Is the Gulf Stream responsible for Europe's mild winters? Q. J. Roy. Meteor. Soc., 128, 2563-2586, 2002.

Seppä, H. and Birks, H. J. B.: July mean temperature and annual precipitation trends during the Holocene in the Fennoscandian tree-line area: pollen-based climate reconstructions, The Holocene, 11, 527-539, 2001.

Seppä, H. and Birks, H. J. B.: Holocene climate reconstructions from the Fennoscandian tree-line area based on pollen data from Toskaljavri, Quatern. Res., 57, 191-199, 2002.

Seppä, H., Nyman, M., Korhola, A., and Weckström, J.: Changes in treelines and alpine vegetation in relation to post-glacial climate dynamics in northern Fennoscandia based on pollen and chironomid records, J. Quatern. Sci., 17, 287-301, 2002.

Seppä, H., Birks, H. J. B, Odland, A., Poska, A., and Veski, S.: A modern pollen-climate calibration set from northern Europe: testing and developing a tool for palaeoclimatological reconstructions, J. Biogeography, 31, 251-267, 2004.

Seppä, H., Hammarlund, D., and Antonsson, K.: Low- and highfrequency changes of temperature and effective humidity during the Holocene in south central Sweden: Implications for atmospheric and oceanic forcings of climate, Clim. Dyn., 25, 285297,2005

Severinghaus, J. P. and Brook, E. J.: Abrupt climate change at the end of the last glacial period inferred from trapped air in polar ice, Science, 286, 930-934, 1999.

Snowball, I., Zillén, L., and Gaillard, M. J.: Rapid early-Holocene environmental changes in northern Sweden based on studies of two varved lake-sediment sequences, The Holocene, 12, 7-16, 2002.

Sorvari, S., Korhola, A., and Thompson, R.: Lake diatom response to recent Arctic warming in Finnish Lapland, Global Change Biol., 8, 153-163, 2002.

Spieksma, F. Th. M., Corden, J. M., Detandt, M., Millington, W. M., Nikkels, H., Nolard, N., Schoenmakers, C. H. H., Wachter, R., de Weger, L. A., Willems, R., and Emberlin, J.: Quantitative trends in annual totals of five common airborne pollen types (Betula, Quercus, Poaceae, Urtica, and Artemisia), at five pollenmonitoring stations in western Europe, Aerobiologia, 19, 171184, 2003.
Spurk, M., Leuschner, H. H., Baillie, M. G. L., Briffa, K. R., and Friedrich, M.: Depositional frequency of German fossil oaks: climatically and non-climatically induced fluctuations in the Holocene, The Holocene, 12, 707-715, 2002.

Stocker, T.: Past and future reorganisations in the climate system, Quatern. Sci. Rev., 19, 301-319, 2000.

Stouffer, R. J., Yin, J., Gregory, J. M., Dixon, K. W., Spelman, M. J., Hurlin, W., Weaver, A. J., Eby, M., Flato, G. M., Hu, A., Jungclaus, J. H., Kamenkovich, I. V, Levermann, A., Montoya, M., Murakami, S., Nawrath, S., Oka, A., Peltier, W. R., Robitaille, D. Y., Sokolov, A., Vettoretti, G., and Weber, S. L.: Investigating the Causes of the Response of the Thermohaline Circulation to Past and Future Climate Changes, J. Climate, 19, 1365-1387, 2006.

Sutton, R. T. and Hodson, D. L. R.: Influence of the Ocean on North Atlantic Climate Variability 1871-1999, J. Climate, 16, 32963313, 2003.

ter Braak, C. J. F. and Juggins, S.: Weighted averaging partial least squares regression (WA-PLS): an improved method for reconstructing environmental variables from species assemblages, Hydrobiologia, 269/270, 485-502, 1993.

Veski, S., Seppä, H., and Ojala, A. E. K.: Cold event at 8200 yr B.P. recorded in annually laminated lake sediments in eastern Europe, Geology, 32, 681-684, 2004.

von Grafenstein, U., Erlenkeuser, H., Müller, J., Jouzel, J., and Johnsen, S.: The cold event 8200 years ago documented in oxygen isotope records of precipitation in Europe and Greenland, Clim. Dyn., 14, 73-81, 1998.

Walther, A. and Linderholm, H. W.: A comparison of growing season indices for the Greater Baltic Area, Int. J. Biometeorol., 51, 107-118, 2006.

Wielgolaski, F.-E.: Starting dates and basic temperatures in phenological observation of plants, Int. J. Biometeorol., 42, 158-168, 1999.

Wiersma, A. P. and Renssen, H.: Model-data comparison for the 8.2 ka BP event: Confirmation of a forcing mechanism by catastrophic drainage of Laurentide Lakes, Quatern. Sci. Rev., 25, 6388, 2006

Wiersma, A. P., Renssen, H., Goosse, H., and Fichefet, T.: Evaluation of different freshwater forcing scenarios for the $8.2 \mathrm{ka}$ BP event in a coupled climate model, Clim. Dyn., 27, 831-849, doi:10.1007/s00382-006-0166-0, 2006.

$\mathrm{Wu}, \mathrm{P}$. and Rodwell, M. J.: Gulf Stream forcing of the winter North Atlantic oscillation, Atmos. Sci. Lett., 5, 57-64, 2004.

Wunsch, C.: Abrupt climate change: An alternative view, Quatern. Res., 65, 191-203, 2006. 